\title{
EFEKTIVITAS ANTIHIPERGLIKEMIA TABLET CAMPURAN EKSTRAK DAUN PEPAYA DAN DAUN SALAM PADA TIKUS Sprague dawley
}

\author{
Erni Rustiani ${ }^{1}$, Min Rachminiwati ${ }^{2}$, Lia Suryani ${ }^{3}$ \\ ${ }^{1,3}$ Program Studi Farmasi, Fakultas MIPA, Universitas Pakuan Bogor \\ ${ }^{2}$ Fakultas Kedokteran Hewan, Institut Pertanian Bogor \\ 1e_rustiani@yahoo.com
}

\begin{abstract}
Plants which have a potential effect as antihyperglycemic are papaya leaf and bay leaf. Papaya leaf and bay leaf have a bioactive flavonoid component, which was suggested to have reduction effect on blood glucose. The purpose of this research was to examine the effectiveness of papaya leaf and bay leaf extract, which have been formulated in tablet form to decrease blood glucose level on diabetic Sprague dawley rats induced by alloxan. Twenty male rats were divided into four groups, Each group consists of five rats, namely group I as a positive control (metformin $12.6 \mathrm{mg} / 200 \mathrm{~g} \mathrm{BW}$ ), group II (oral tablet $1.282 \mathrm{mg} / 200 \mathrm{~g} \mathrm{BW}$ ), group III (oral tablet $2.564 \mathrm{mg} / 200 \mathrm{~g} \mathrm{BW}$ ) as extract treatment group, and group IV as negative control. The treatment was carried out for 28 days. The result of this research showed that tablet of papaya leaf and bay leaf extract can be used as antihyperglycemic with the most effective dose was $2.564 \mathrm{mg} / 200 \mathrm{~g} B \mathrm{~B}$ (group III) and the treatment for twelve days.
\end{abstract}

Keywords: Antihyperglycemic, Papaya leaf, bay leaf, tablet

\section{PENDAHULUAN}

Diabetes adalah kelompok penyakit metabolik kompleks yang ditandai oleh suatu keadaan hiperglikemia yaitu meningkatnya kadar gula darah melebihi kadar normal (Auroma et al., 2006). Menurut WHO, diabetes adalah ancaman yang meningkat bagi kesehatan masyarakat. Studi epidemeologi terhadap penderita diabetes menunjukkan dari 30 juta penduduk dunia yang menderita diabetes pada tahun 1985 meningkat menjadi 171 juta jiwa pada tahun 2000. Badan Kesehatan Dunia (WHO) memperkirakan pada tahun 2030 jumlah penderitanya akan melonjak menjadi 366 juta jiwa. Indonesia menempati peringkat ke-4 jumlah penderita diabetes terbanyak setelah India, Cina dan Amerika Serikat. Jumlahnya 8,4 juta pada tahun 2000 dan diperkirakan meningkat menjadi 21,3 juta pada tahun 2030 (Wild et al., 2004).

Daun pepaya secara medis dapat dimanfaatkan untuk pengobatan. Pada ekstrak daun pepaya terdapat kandungan alkaloid, saponin, tanin dan flavonoid yang memiliki aktivitas sebagai antioksidan dan dapat mengurangi kadar gula darah dengan dosis $5,0 \mathrm{mg} / 200 \mathrm{~g}$ BB tikus (Fakeye et al., 2007). Daun salam selain penggunaannya sebagai penyedap masakan, dapat digunakan sebagai bahan ramuan dalam pengobatan seperti asam urat, kolesterol dan anti diabetes. Daun salam mengandung antidiabetik karena memiliki senyawa aktif seperti eugenol, tanin dan flavonoid (Taufiqurrohman, 2015). Ekstrak daun salam dengan dosis 5,5g/200g BB tikus memiliki aktivitas antihiperglikemik. Kedua tanaman tersebut mengandung flavonoid sebagai antioksidan (Musyrifah $d k k, 2012$ ).
Berdasarkan kesamaan khasiat daun papaya dan daun salam untuk pengobatan diabetes, maka telah dilakukan pembuatan sediaan tablet oleh Rahmahuda (2016). Formula dengan mutu terbaik terdiri dari ekstrak daun papaya 40mg, ekstrak daun salam 10,88mg dan bahan tambahan PVP K-30, Ac-Di-Sol, $\mathrm{Mg}$ stearate, talk serta avicel PH 102. Mekanisme kerja flavonoid adalah sebagai antioksidan yang bertindak sebagai pendonor atom hidrogen yang mampu mengikat radikal bebas atau Reactive Oxygen Spesies (Kaneto et al, 1999).

Khasiat tablet campuran ekstrak daun pepaya dan daun salam yang telah dibuat Rahmahuda (2016) belum teruji secara ilmiah, oleh karena itu perlu dilakukan penelitian untuk menguji efektivitasnya. Penelitian ini bertujuan menentukan efektivitas tablet campuran ekstrak daun papaya dan daun salam sebagai antihiperglikemia pada tikus Sprague Dawley yang diinduksi aloksan.

\section{METODE PENELITIAN}

A. Alat dan Bahan

Bahan yang digunakan dalam penelitian ini adalah tablet campuran ekstrak daun pepaya dan daun salam, tikus putih jantan Sprague Dawley, aloksan, metformin, alkohol 70\%, pellet B512 dan sekam. Alatalat yang digunakan dalam penelitian ini antara lain timbangan digital, sonde oral, alat pengukur gula darah atau glukometer Eassy Touch ${ }^{\circledR}$, vortex, spuit atau alat suntik $1 \mathrm{cc}$ atau $2 \mathrm{cc}$, sarung tangan, masker, kandang tikus dan alat-alat gelas lainnya. 


\section{B. Penetapan Dosis}

Penetapan dosis tikus untuk pemberian aloksan adalah 150mg/kgBB (Prabawati, 2015). Sedangkan dosis tablet diberikan berdasarkan penelitian Rahmahuda (2016). Setiap 1 tablet mengandung ekstrak daun papaya dan ekstrak daun salam 50,88mg/200grBB. Dosis I sesuai dengan dosis tersebut sedangkan dosis II merupakan $2 \mathrm{x}$ $50,88 \mathrm{mg} / 200 \mathrm{grBB}$. Kontrol positif yang digunakan adalah tablet metformin $500 \mathrm{mg} / \mathrm{kgBB}$ (Prabawati, 2016).

\section{Pemeliharaan Hewan Coba}

Hewan uji yang digunakan adalah tikus putih jantan Sprague Dawley (Rattus norvegicus L.) galur Sprague Dawley sebanyak 24 ekor dengan bobot \pm 200 g berumur 3-3,5 bulan. Tikus diaklimatisasi selama 1 minggu dalam kandang karantina Laboratorium Farmakologi FMIPA Universitas Pakuan. Aklimatisasi bertujuan agar tikus beradaptasi dengan lingkungan baru dan mengurangi efek stress pada tikus yang dapat berpengaruh pada metabolisme yang dapat mengganggu penelitian.

\section{Induksi Aloksan}

Sebelum diinduksi dengan aloksan, tikus dipuasakan dahulu selama 12 jam dan hanya diberi air minum, kemudian diukur kadar gula darah puasanya. Setelah dilakukan pengukuran, tikus diinjeksi aloksan $150 \mathrm{mg} / \mathrm{kgBB}$ secara intraperitoneal. Tikus yang telah diinduksi dengan Aloksan dibiarkan selama 3 hari menunggu adanya kenaikan gula darah. Hanya tikus dengan kadar gula darah $\geq 200 \mathrm{mg} / \mathrm{dl}$ atau kadar gula darah puasa $\geq 126 \mathrm{mg} / \mathrm{dl}$ yang digunakan dalam penelitian ini.

\section{Pengujian Tablet Pada Hewan Coba}

1. Induksi Aloksan

Sebelum diinduksi dengan aloksan, tikus dipuasakan dahulu selama 12 jam dan hanya diberi air minum, kemudian diukur kadar gula darah puasanya. Setelah dilakukan pengukuran, tikus diinjeksi aloksan $150 \mathrm{mg} / \mathrm{kgBB}$ secara intraperitoneal. Tikus yang telah diinduksi dengan Aloksan dibiarkan selama 3 hari menunggu adanya kenaikan gula darah. Hanya tikus dengan kadar gula darah $\geq 200 \mathrm{mg} / \mathrm{dl}$ atau kadar gula darah puasa $\geq 126 \mathrm{mg} / \mathrm{dl}$ yang digunakan dalam penelitian ini.

\section{Pemberian Tablet}

Setelah hewan coba diinduksi aloksan dan kadar gula darahnya mencapai $\geq 200 \mathrm{mg} / \mathrm{dl}$ hewan coba tersebut dibagi menjadi 4 kelompok perlakuan. Masing-masing kelompok terdiri dari 6 ekor tikus, pemberian obat secara oral. Kelompok I : Kontrol positif yang diberi metformin dengan dosis 500mg/200gram BB. Kelompok II: Dosis I (dosis awal) tablet campuran ekstrak daun pepaya dan ekstrak daun salam $1,282 \mathrm{mg} / 200$ gram BB untuk satu kali pemberian dalam sehari. Kelompok III : Dosis II $(2 \mathrm{x}$ dosis awal) tablet yaitu 2,564mg/200gramBB untuk satu kali pemberian dalam sehari. Kelompok IV : Kontrol negatif hanya diberikan pakan dan air minum tanpa diberikan suatu perlakuan.

\section{Pengukuran Kadar Glukosa Darah}

Pengujian antidiabetes pada tikus dilakukan dengan menggunakan alat Easy Touch ${ }^{\circledR}$ yang diambil darah dari ekornya. Pengamatan kadar glukosa darah dilakukan setelah aklimatisasi selama 7 hari. Diinduksi dalam keadaan normal dan pengukuran kadar glukosa darah pada hari ke $0,4,8,12,16,20$ setelah pemberian perlakuan. Bila kadar glukosa telah kembali seperti normal, perlakuan diteruskan selama maksimal 20 hari.

\section{E. Rancangan Penelitian}

Data-data yang diperoleh dianalisa dengan analisis sidik ragam untuk rancangan acak lengkap (RAL) pola faktorial kombinasi perlakuan $4 \times 8$ menggunakan program SPSS.

\section{HASIL DAN PEMBAHASAN Pengukuran Kadar Gula Darah Pada Tikus Selama Perlakuan}

Rata-rata kadar gula darah tikus sebelum diinduksi aloksan adalah 111,55 $\pm 5,72 \mathrm{mg} / \mathrm{dl}$, setelah dilakukan induksi kadar gula darah tikus meningkat menjadi 239,1 $\pm 1,18 \mathrm{mg} / \mathrm{dl}$. Aloksan menyebabkan diabetes pada tikus dengan cara merusak sel yang mensekresi insulin pankreas yang menyebabkannya hiperglikemia (Ewenighi,2015).

Hasil pengukuran kadar gula darah tikus yang diberi perlakuan tablet campuran ekstrak daun pepaya dan ekstrak daun salam dengan dosis 2,564 mg/200 g BB (Dosis II) menunjukkan adanya penurunan kadar gula darah di hari ke 12, menuju level normal. Kadar gula darah stabil mulai hari ke 20 sampai hari ke 28 . Rata-rata kadar gula darah tikus dapat dilihat pada Tabel 1 dan Gambar 1. 
Tabel 1. Rata-Rata Kadar Gula Darah Tikus Berdasarkan Lama Pemberian

\begin{tabular}{|c|c|c|c|c|c|}
\hline \multirow{2}{*}{ Perlakuan } & \multicolumn{4}{|c|}{ Rata - rata \pm SD Kadar Gula Darah Pada Tikus (mg/dl) } & \multirow{2}{*}{ Rata-rata } \\
\hline & Kontrol (+) & Dosis I & Dosis II & Kontrol (-) & \\
\hline Hari ke -3 & $104,0 \pm 7,38$ & $113,6 \pm 23,26$ & $111,0 \pm 11,38$ & $117,6 \pm 12,64$ & $111,6 \pm 5,72^{\mathrm{a}}$ \\
\hline Hari ke 0 & $238,4 \pm 24,63$ & $240,2 \pm 27,26$ & $240,0 \pm 28,78$ & $237,8 \pm 24,44$ & $239,1 \pm 1,18^{f}$ \\
\hline Hari ke 4 & $177,8 \pm 7,05$ & $189,6 \pm 9,26$ & $182,0 \pm 8,51$ & $244,6 \pm 24,76$ & $198,5 \pm 31,12^{\mathrm{e}}$ \\
\hline Hari ke 8 & $156,4 \pm 7,23$ & $172,6 \pm 8,44$ & $165,6 \pm 9,13$ & $246,4 \pm 23,33$ & $185,3 \pm 41,30^{\mathbf{d}}$ \\
\hline Hari ke 12 & $140,0 \pm 12,55$ & $156,4 \pm 6,66$ & $155,4 \pm 11,04$ & $246,4 \pm 18,98$ & $174,6 \pm 48,48^{c}$ \\
\hline Hari ke 16 & $135,0 \pm 11,34$ & $151,4 \pm 8,08$ & $149,8 \pm 11,45$ & $249,4 \pm 20,29$ & $171,4 \pm 52,52^{\mathbf{b c}}$ \\
\hline Hari ke 20 & $128,2 \pm 10,35$ & $147,2 \pm 8,87$ & $146,2 \pm 11,73$ & $244,8 \pm 17,71$ & $166,6 \pm 52,86 b^{c}$ \\
\hline Hari ke 24 & $126,4 \pm 10,43$ & $144,8 \pm 8,70$ & $142,4 \pm 13,13$ & $241,8 \pm 15,07$ & $163,85 \pm 52,60^{\mathbf{b}}$ \\
\hline Hari ke 28 & $122,2 \pm 10,94$ & $142,8 \pm 8,35$ & $140,6 \pm 12,60$ & $238,4 \pm 14,94$ & $161,0 \pm 52,42^{\mathbf{b}}$ \\
\hline Rata-rata & $147,6 \pm 40,04^{a}$ & $162,1 \pm 35,98^{\mathbf{b}}$ & $159,2 \pm 35,90^{\mathbf{b}}$ & $229,7 \pm 42,20^{\mathbf{c}}$ & \\
\hline & $\begin{array}{l}\text { ri }-3 \\
\text { ri ke } 0 \\
\text { ri ke } 0-28\end{array}$ & adar gula daral & $\begin{array}{l}\text { ormal (sebelum } \\
\text { telah diinduks } \\
\text { lama pengobat }\end{array}$ & $\begin{array}{l}\text { induksi aloksan) } \\
\text { oksan }\end{array}$ & \\
\hline
\end{tabular}

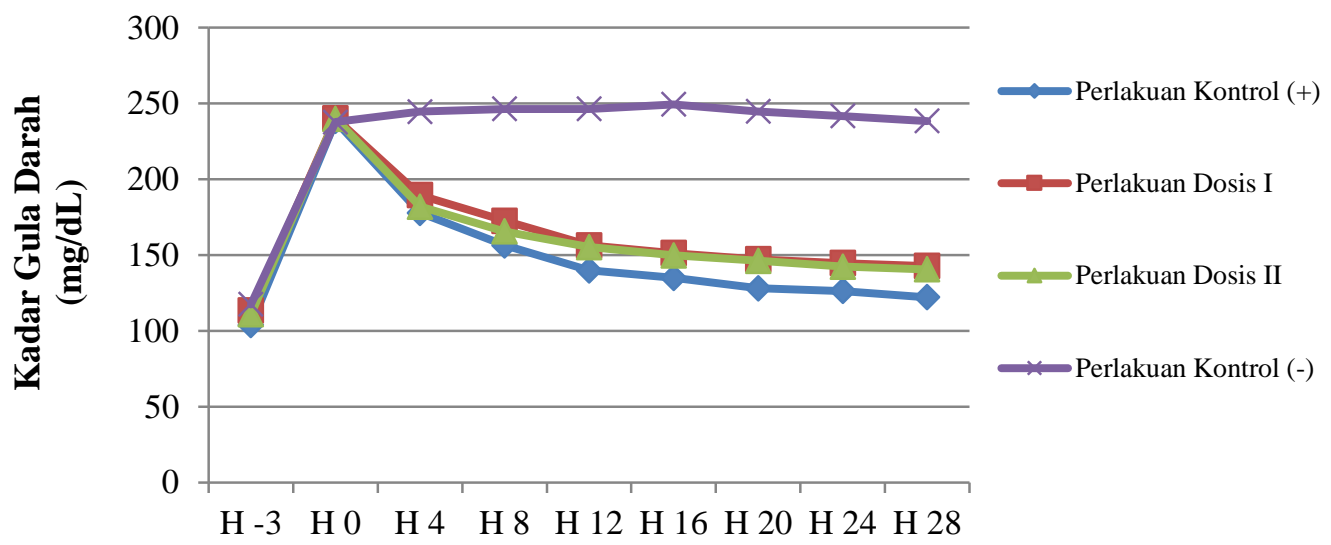

Perlakuan

Gambar 1. Grafik Rata-Rata Kadar Gula Darah Tikus Berdasarkan Lama Pemberian

Hasil uji lanjut Duncan menunjukkan sediaan tablet campuran ekstrak daun pepaya dan daun salam pada dosis I dan dosis II mempunyai pengaruh yang signifikan terhadap kadar gula darah, namun besarnya efek menurunkan kadar gula darah masih berada dibawah efek kontrol positif.

Penurunan kadar gula darah merupakan salah satu manfaat flavonoid yang terdapat dalam daun salam dan daun pepaya. Flavonoid mempengaruhi transportasi glukosa dalam darah melalui peningkatan sekresi insulin, menurunkan apoptosis, membantu proliferasi beta sel pankreas, menurunkan resistensi insulin, inflamasi dan stres oksidatif pada otot (Hossain et. al, 2016).

Pengukuran Berat Badan Pada Tikus Selama Perlakuan

Berat badan tikus menunjukkan adanya perubahan sebelum induksi dan sesudah induksi 3 hari. Rata-rata berat badan tikus sebelum dan sesudah diinduksi mengalami penurunan, Kelompok kontrol 
negatif memiliki persentase penurunan berat badan yang paling tinggi yaitu sebesar 10,74 \%, diikuti berat badan kontrol positif. Pada tikus diabetes yang tidak diobati menunjukkan penurunan berat badan karena terjadi perubahan glukosa, metabolisme lipid dan modifikasi enzim hati (Ewenighi, 2015). Rata-rata berat badan tikus dapat dilihat pada Tabel 2 dan Gambar 2

Tabel 2. Rata-Rata Berat Badan Tikus Berdasarkan Lama Pemberian

\begin{tabular}{|c|c|c|c|c|c|}
\hline \multirow{2}{*}{ Perlakuan } & \multicolumn{4}{|c|}{ Rata-rata \pm SD Berat Badan Pada Tikus (g) } & \multirow{2}{*}{ Rata-rata } \\
\hline & Kontrol (+) & Dosis I & Dosis II & Kontrol (-) & \\
\hline Hari ke -3 & $243,6 \pm 7,23$ & $233,2 \pm 11,30$ & $223,4 \pm 10,06$ & $220,6 \pm 14,50$ & $230,2 \pm 10,44^{\mathrm{d}}$ \\
\hline Hari ke 0 & $226,4 \pm 7,33$ & $214,0 \pm 7,18$ & $204,4 \pm 8,02$ & $198,0 \pm 8,22$ & $210,7 \pm 12,36^{\mathbf{b}}$ \\
\hline Hari ke 4 & $205,2 \pm 12,77$ & $1942 \pm 10,80$ & $186,4 \pm 8,85$ & $179,6 \pm 9,50$ & $191,4 \pm 10,99^{\mathbf{a}}$ \\
\hline Hari ke 8 & $208,2 \pm 13,48$ & $193,8 \pm 11,32$ & $189,8 \pm 10,16$ & $179,0 \pm 11,20$ & $192,7 \pm 12,08^{\mathrm{a}}$ \\
\hline Hari ke 12 & $224,4 \pm 8,35$ & $214,4 \pm 13,15$ & $212,6 \pm 13,05$ & $177,6 \pm 15,58$ & $207,3 \pm 20,44^{\mathbf{b}}$ \\
\hline Hari ke 16 & $236,8 \pm 9,41$ & $235,0 \pm 8,22$ & $233,2 \pm 14,86$ & $174,2 \pm 18,82$ & $219,8 \pm 30,43^{\mathbf{c}}$ \\
\hline Hari ke 20 & $247,6 \pm 7,83$ & $242,0 \pm 7,84$ & $246,2 \pm 15,17$ & $177,2 \pm 19,47$ & $228,3 \pm 34,12^{d}$ \\
\hline Hari ke 24 & $248,4 \pm 8,73$ & $246,4 \pm 9,10$ & $253,0 \pm 14,39$ & $177,2 \pm 17,43$ & $231,3 \pm 36,14^{d}$ \\
\hline Hari ke 28 & $250,2 \pm 8,41$ & $250,2 \pm 8,11$ & $249,0 \pm 12,59$ & $181,2 \pm 19,04$ & $232,65 \pm 34,30^{\mathbf{d}}$ \\
\hline Rata-rata & $232,31 \pm 17,23^{\mathbf{c}}$ & $224,8 \pm 21,52^{\mathbf{b}}$ & $222 \pm 25,26^{\mathbf{b}}$ & $184,96 \pm 15,04^{\mathrm{c}}$ & \\
\hline
\end{tabular}

\begin{tabular}{lll}
\hline Keterangan: & Hari -3 & : Berat badan normal (sebelum induksi) \\
& Hari ke 0 & : Berat badan setelah diinduksi aloksan \\
& Hari ke 0-28 & : Berat Badan selama pengobatan
\end{tabular}

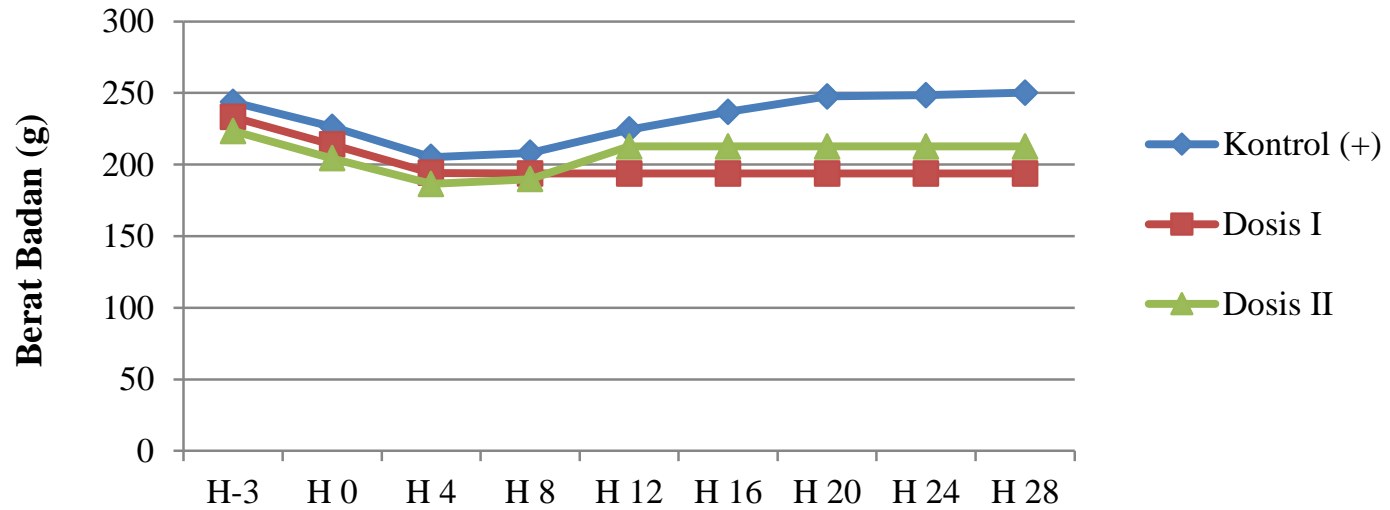

Perlakuan

Gambar 2. Grafik Rata-Rata Berat Badan Tikus Berdasarkan Lama Pemberian

\section{Jumlah Volume Air Minum Pada Tikus Selama Perlakuan}

Dehidrasi dan kehilangan bobot badan berhubungan dengan kondisi diabetes melitus (Pupim, 2005). Rata-rata volume air minum dari hari ke-0, hari ke-4 dan hari ke-8 menunjukkan adanya penurunan volume air minum yang dikonsumsi tikus pada setiap kelompok perlakuan. Gejala polidipsi terlihat dari kenaikan jumlah air minum yang dikonsumsi. Tikus yang diobati dengan metformin dan tablet campuran ekstrak daun pepaya dan daun salam, jumlah minum yang dikonsumsi mengalami penurunan. Tikus yang tidak diberi pengobatan (kontrol negatif) konsumsi minum terus meningkat sampai hari ke-8. Selama 
kadar gula darah belum terkontrol baik akan timbul keinginan untuk minum terus menerus, sebaliknya minum yang banyak akan terus menimbulkan keinginan untuk selalu mengeluarkan urin. Penelitian Rojop et al. (2012) menyebutkan bahwa pengobatan tikus diabetes dengan ekstrak daun pepaya secara signifikan menurunkan konsumsi air minum ( $\mathrm{p}<$ $0,05)$.
Hasil Uji Duncan air minum tikus dapat menunjukkan adanya pengaruh sangat nyata dosis terhadap perubahan air minum pada tikus namun tidak menunjukkan pengaruh terhadap waktu terhadap perubahan air minum yang berarti tidak ada keterkaitan antara dosis terhadap waktu dan terhadap perubahan air minum pada tikus. Rata-rata jumlah air minum yang dikonsumsi tikus dapat dilihat pada Tabel 3 dan Gambar 3.

Tabel 3. Rata-Rata Jumlah Air Minum Tikus Berdasarkan Lama Pemberian

\begin{tabular}{cccccc}
\multirow{2}{*}{ Perlakuan } & \multicolumn{5}{c}{ Rata - rata \pm SD Air Minum Pada Tikus (mL) } \\
\cline { 2 - 5 } & Kontrol (+) & Dosis I & Dosis II & Kontrol (-) & Rata-rata \\
\hline Hari ke 0 & $238,33 \pm 76,54$ & $231,66 \pm 83,86$ & $235 \pm 82,31$ & $281,66 \pm 92,51$ & $246,66 \pm 23,49^{\mathbf{a}}$ \\
Hari ke 4 & $201,66 \pm 75,22$ & $233,33 \pm 81,45$ & $225 \pm 87,18$ & $333.33 \pm 90.05$ & $248.33 \pm 58.23^{\mathbf{a}}$ \\
Hari ke 8 & $143,33 \pm 63,71$ & $166,66 \pm 62,52$ & $145 \pm 56,79$ & $383,33 \pm 136,14$ & $209,58 \pm 116,32^{\mathbf{a}}$ \\
\hline Rata-rata & $194,44 \pm 47,91^{\mathbf{a}}$ & $210,55 \pm 38,02^{\mathbf{a}}$ & $201,67 \pm 49,33^{\mathbf{a}}$ & $332.77 \pm 50.84^{\mathbf{b}}$ & \\
\hline Keterangan: & Hari ke-0 & : Pengecekan hari ke nol volume air minum (setelah 3 hari induksi) \\
& Hari ke-4 & : Pengecekan hari keempat volume air minum & \\
& Hari ke-8 & : Pengecekan hari kedelapan volume air minum &
\end{tabular}

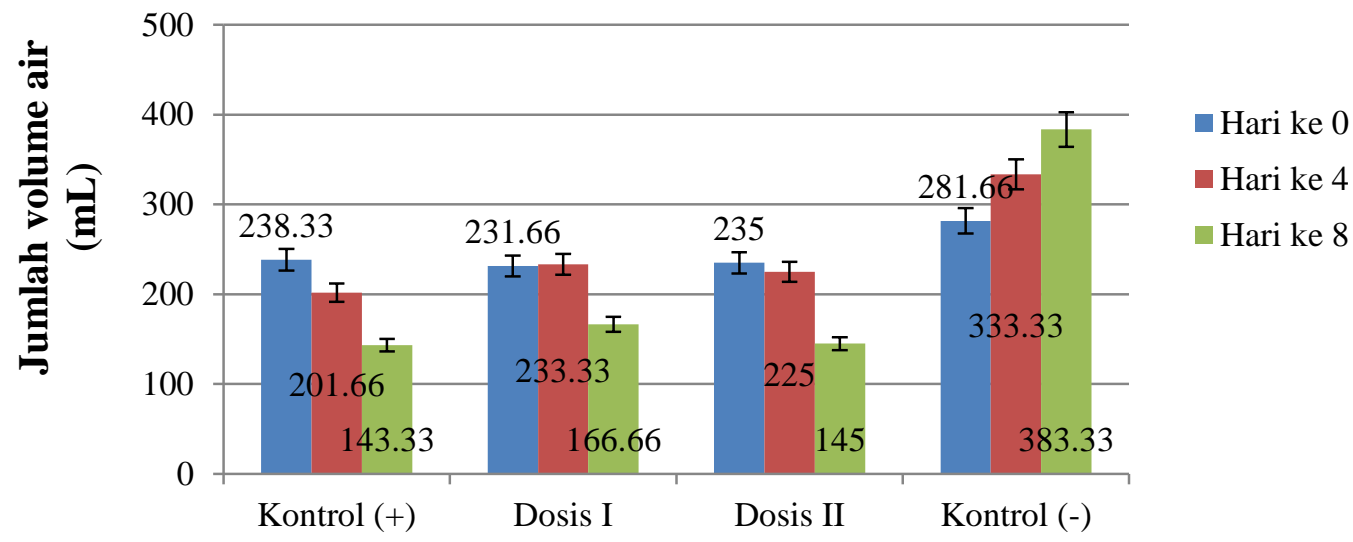

\section{Perlakuan}

Gambar 3. Grafik Rata-Rata Jumlah Air Minum Tikus Berdsarkan Lama Pemberian

\section{Konsumsi Pakan Tikus Selama Perlakuan}

Gejala khas diabetes melitus tipe 2 adalah tingginya kebutuhan makanan dan minuman yang berhubungan dengan penurunan berat badan (Montano, 2010). Konsumsi pakan ditentukan dengan mengumpulkan dan menimbang pakan sisa dinyatakan dalam satuan gram. Gejala polipagi terlihat dari kenaikan jumlah konsumsi pakan setiap kelompok perlakuan pada hari ke-0 setelah diinduksi aloksan.
Tikus yang diobati dengan metformin dan tablet campuran ekstrak daun pepaya dan daun salam, jumlah pakan yang dikonsumsinya cenderung mengalami penurunan. Tikus yang tidak diberi pengobatan (kontrol negatif) konsumsi makannya terus meningkat sampai hari ke-8. Rata-rata jumlah pakan yang dikonsumsi tikus dapat dilihat pada Tabel 4 dan Gambar 4. 
Tabel 4. Rata-Rata Konsumsi Pakan Tikus Berdasarkan Lama Pemberian

\begin{tabular}{cccccc}
\hline \multirow{2}{*}{ Perlakuan } & \multicolumn{5}{c}{ Rata - rata \pm SD Pakan B512 Pada Tikus (g) } \\
\cline { 2 - 6 } & Kontrol (+) & Dosis I & Dosis II & Kontrol (-) & Rata-rata \\
\hline Hari ke 0 & $167,0 \pm 62.39$ & $168.6 \pm 72.60$ & $165.7 \pm 63.52$ & $177,0 \pm 68.04$ & $169.6 \pm 5.10$ \\
Hari ke 4 & $155.3 \pm 48.43$ & $187.7 \pm 67.26$ & $176.7 \pm 76.54$ & $212.6 \pm 67.35$ & $183.1 \pm 23.86$ \\
Hari ke 8 & $119.7 \pm 39.02$ & $168.3 \pm 67.86$ & $148.7 \pm 62.13$ & $220,0 \pm 78.10$ & $164.2 \pm 42.25$ \\
\hline Rata-rata & $147.3 \pm 24.66$ & $174.9 \pm 11.08$ & $163.66 \pm 14.11$ & $203.2 \pm 23.01$ \\
\hline Keterangan: & \multicolumn{4}{l}{ Hari ke-0: Pengecekan hari ke nol konsumsi makan (setelah 3 hari induksi) } \\
& Hari ke-4: Pengecekan hari keempat konsumsi makan \\
& Hari ke-8: Pengecekan hari kedelapan konsumsi makan &
\end{tabular}

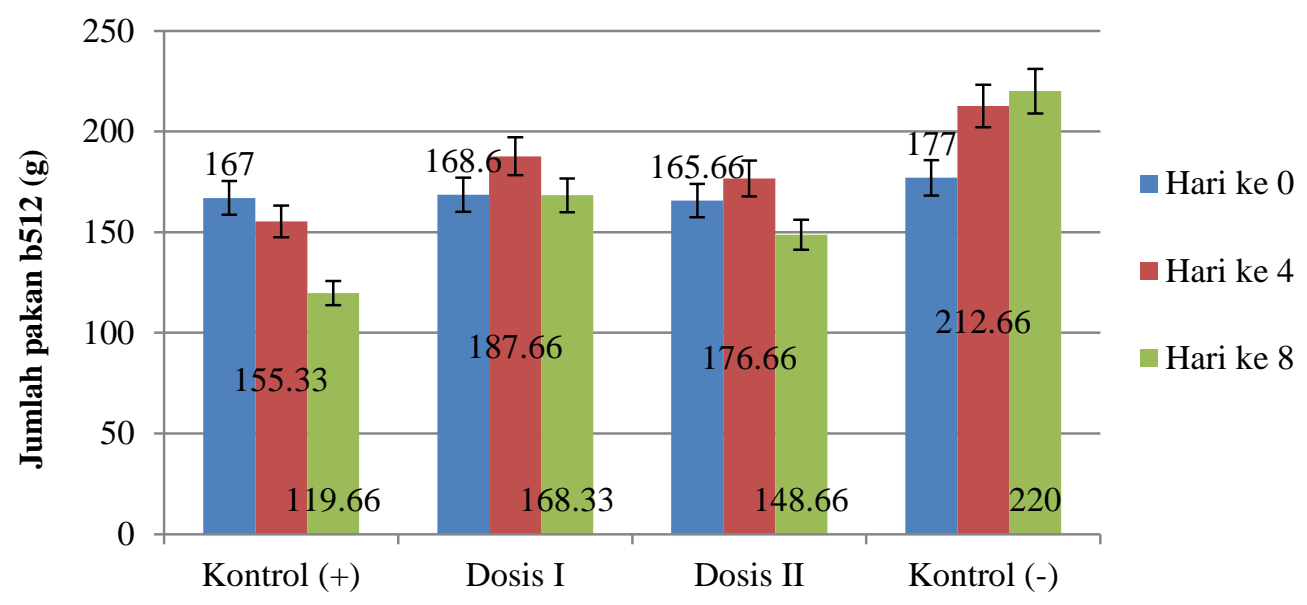

Perlakuan

Gambar 4. Grafik Rata-Rata Jumlah Pakan B512 Tikus Berdasarkan Lama Pemberian

\section{KESIMPULAN}

Berdasarkan hasil penelitian yang dilakukan dapat disimpulkan :

1. Tablet ekstrak daun pepaya dan daun salam dengan dosis 2,564 mg/200g BB (dosis II) memiliki potensi sebagai antihiperglikemia.

2. Pemberian sediaan tablet ekstrak daun pepaya dan daun salam dapat menurunkan kadar gula darah tikus dengan waktu pengobatan selama 12 hari dan tetap stabil hingga hari ke 28 .

\section{DAFTAR PUSTAKA}

Auroma, O.I., Neergheen, V.S., Bahorum, T., Jen, L.S. 2006. Free radicals, antioxidants and diabetes: embryopathy, retinopathy, neuropathy, nephropathy, and cardiovascular complications. Neuroembryol Aging 4: 117-137.

Ewenighi C., Uchechukwu D., Joel O., Linus O., Gladys O., Uchechukwu E. 2015. Estimation of Glucose Level and Body Weight in
Alloxan Induced Diabetic Rat Treated with Aqueous Extract of Garcinia Kola Seed. Ulutas Med Journal. 1(2):26-30

Hossain, M.K., Ahmed, A.D., Jihae H., Yingfu Y., Kyeongseok K., Subbroto K.S., GwangMo Y., Hye Y.S., Ssang-Goo C. 2016. Molecular Mechanisms of the AntiObesity and Anti-Diabetic Properties of Flavonoids. International Journal of Molecular Sciences. 17, 569.

Kaneto, H., Kajimoto, Y., Miyagawa, J., Matsuoka, T. 1999. Beneficial effects of antioxidants in diabetes: Possible protection of pancreatic $\beta$ Cells against glucose toxicity. Diabetes. 48 : 2398-2406.

Montano, M.E, Molpeceres,V, MaurizJ.L, Garzo E, Cruz I.B, Gonzalez P, Barrio J.P. 2010. Effect of melatonin supplementation on food and water intake in streprozocin-diabetic and nondiabetic male Wistar rats. Nutr Hosp. 25:931938. 
Musyrifah, S., Utaminingsih, B. dan Laili, F.N. 2012. Pastiles Daun Salam (Eugenia Polyantha W). Yogyakarta: Universitas Gajah Mada.

Pournaghi, P, Rajab-Ali S., Shapour H., Azadeh F. 2012. An investigation on body weights, blood glucose levels and pituitary-gonadal axis hormones in diabetic and metformintreated diabetic female rats Veterinary research forum. 3(2), 79-84.

Prabawati, M. 2015. Optimasi Dosis Granul Instan Ekstrak Daging Buah Mahkota Dewa Dan Daun Salam Sebagai Antihiperglikemik Pada Tikus Putih Jantan. Skripsi. FMIPA. Universitas Pakuan, Bogor.

Pupim L.B., Heimburger O., Qureshi A.R., Ikizler T.A., Stenvinkel P. 2005. Accelerated lean body mass loss in incident chronic dialysis patients with diabetes mellitus. Kidney Int. 68:2368-2374.

Rahmahuda, NK. 2014. Formulasi Sediaan Tablet Kombinasi Ekstrak Daun Pepaya Dan Daun Salam Dengan Variasi Konsentrasi Pengikat PVP K-30. Skripsi. FMIPA. Universitas Pakuan, Bogor.

Rojop I.E.J, Juan C, Jorge L.B, Pedro H.M.O, Andres E.C.R, Carlos A.T.Z, Arturo R.H, Hidemi A.M, Teresa R.E, Deysi Y.B.O. 2012. Hypoglycemic effect of Carica papaya leaves in streptozotocin-induced diabetic rats. $B M C$ Complementary and Alternative Medicine. 12:236.

Taufiqurrohman. 2015. Indonesian bay leaves as antidiabetic for type 2 diabetes mellitus. $\mathrm{J}$ Majority. 4 (3): 101-108.

Wild, S., Roglic, G., Green, A., Sicree, R., King, H. 2004. Global prevalence of diabetes. Diabetes Care 27: 1047-1053. 